\title{
Pathways to educational success among refugees: Connecting locally and globally situated resources.
}

\section{Citation}

Dryden-Peterson, Sarah, Negin Dahya, and Elizabeth Adelman. 2017. Pathways to educational success among refugees: Connecting locally and globally situated resources. American

Educational Research Journal

\section{Published Version}

http://journals.sagepub.com/doi/full/10.3102/0002831217714321

\section{Permanent link}

http://nrs.harvard.edu/urn-3:HUL.InstRepos:33339105

\section{Terms of Use}

This article was downloaded from Harvard University's DASH repository, and is made available under the terms and conditions applicable to Open Access Policy Articles, as set forth at http:// nrs.harvard.edu/urn-3:HUL.InstRepos:dash.current.terms-of-use\#OAP

\section{Share Your Story}

The Harvard community has made this article openly available.

Please share how this access benefits you. Submit a story.

Accessibility 


\title{
Pathways to educational success among refugees: Connecting local and global resources in the Dadaab camps of Kenya
}

\author{
Sarah Dryden-Peterson $^{\mathrm{a}}$, Negin Dahya ${ }^{\mathrm{b}}$, and Elizabeth Adelman ${ }^{\mathrm{a}}$ \\ ${ }^{\mathrm{a}}$ Harvard Graduate School of Education \\ ${ }^{\mathrm{b}}$ University of Washington
}

Corresponding Author:

Sarah Dryden-Peterson

Associate Professor of Education

Harvard Graduate School of Education

6 Appian Way

Gutman Library 457

Cambridge, MA 02138 USA

Tel: 617-495-8162/ 617-435-2344

Email: sarah_dryden-peterson@gse.harvard.edu

Negin Dahya

Assistant Professor

The Information School

University of Washington

Mary Gates Hall 015A

Seattle, WA 98195 USA

Elizabeth Adelman

Doctoral Candidate

Harvard Graduate School of Education

6 Appian Way

Cambridge, MA 02138 USA

\section{Biographical Sketches}

Sarah Dryden-Peterson is an Associate Professor of Education at the Harvard Graduate School of Education. Her research focuses on education in armed conflict and the ways in which learning, pedagogies, and relationships may alter trajectories of conflict for nation-states and individuals.

Negin Dahya is an Assistant Professor at the Information School at the University of Washington. Her research explores how social and cultural contexts shape digital media production, social media participation, and technology use for girls and women.

Elizabeth Adelman is an advanced doctoral candidate at the Harvard Graduate School of Education. Her research explores the experiences of teachers working in conflict-affected settings and how they understand their educational, social, and emotional obligations towards their refugee students. 


\title{
Pathways to educational success among refugees: Connecting locally- and globally-situated resources
}

\begin{abstract}
This study identifies pathways to educational success among refugees. Data are from an original online survey of Somali diaspora and in-depth qualitative interviews with Somali refugee students educated in the Dadaab refugee camps of Kenya. This research builds on Bronfenbrenner's ecological model, to consider both the locally- and globally-situated nature of resources across refugees' ecosystems. Analysis examines the nature and content of studentidentified supports and their perceived influence on access and persistence in school, as well as the mediating role of technology. The findings suggest consideration of both locally-situated relationships and globally-situated relationships, as critical educational supports. Implications include leveraging naturally occurring virtual relationships to support educational success of refugees and other young people who are physically isolated from access to needed supports in their local region.
\end{abstract}

\section{Keywords}

Refugee, globalization, academic support, comparative education, migration

\section{Introduction}

"It's always really difficult to move on when you can't see the light at the end of the tunnel," said Mahad ${ }^{1}$, in describing his trajectory through education. Mahad is a Somali refugee living in the Dadaab refugee camps, clustered in a small stretch of desert in eastern Kenya. There are not many places on earth where "the light at the end of the tunnel" is more difficult to see 
than in the Dadaab camps. Together these camps have grown over the past three decades from 90,000 to 463,000 residents, almost all of whom have fled on-going conflict in Somalia (UNHCR, 2015). As the largest refugee camp complex in the world, the Dadaab camps also represent the largest population of Somalis outside of Somalia (Hammond et al., 2011). In these camps, the net enrollment rate for secondary school is only 2.3 percent, and the Gender Parity Index is 0.38 , meaning that there are only 38 girls enrolled for every 100 boys (UNHCR, 2014). Refugees, like Mahad, are some of the most educationally marginalized children in the world. Indeed, more than half of the 58 million children who remain out of school globally live in conflict-affected settings (UNESCO, 2015). Refugees are defined by the 1951 Convention Relating to the Status of Refugees as individuals who have fled across an international border due to a well-founded fear of persecution (UNHCR, 2010). In 2015, the number of refugees globally was 21.3 million, the highest level since World War II; more than half were children under the age of 18 (UNHCR, 2016). Eighty-six percent of these refugees live in exile in neighboring host countries (UNHCR, 2016), usually characterized by already over-stretched education systems. Only one percent of refugees are resettled to countries such as the United States and Canada (UNHCR, 2016), with highly-resourced education systems. ${ }^{2}$ Globally, about half of refugees live in cities and half in refugee camps, although the numbers vary substantially between countries (UNHCR, 2016).

The conflicts that cause individuals to become refugees are not short-lived and have farreaching implications for education. In 2014, in 33 conflicts globally, the average length of displacement for refugees was 25 years (UNHCR \& Global Monitoring Report, 2016). As a result, millions of children globally spend their entire childhoods engulfed in conflict with limited opportunities for education. Global commitments to Education for All and the 
Sustainable Development Goals will not be realized unless the educational needs of refugee children are met. Moreover, education for children in conflict settings is essential to ending existing conflict, rebuilding after conflict, and preventing conflict in the first place (Davies, 2004).

Mahad has lived in a setting of conflict his entire life: first in war-torn Somalia until the age of 6 and then in the Dadaab refugee camps up to the present, at his current age of 22. Unlike the vast majority of his peers, Mahad was able to go to school. He completed both his primary and secondary education in the Dadaab camps, is now a secondary school math teacher, and dreams of "serving my people in the future...by help[ing] the community and promot[ing] education...to transform society." Students like Mahad, who live in conflict settings, have navigated challenges, and have been successful in their education, can provide lessons about the barriers to education in these contexts but also about the pathways to success.

In this article, we seek to identify pathways to educational success among refugees who live in the most common site of exile: neighboring host countries with fragile political, economic, and educational institutions. We do so by analyzing the educational trajectories of students who have been successful in their education, which, for the purposes of this analysis, we define as having graduated from secondary school. In this research, we find that refugee students identify multiple layers of interconnected supports that have enabled their success in education. They focus specifically on relational supports, in particular relationships with international agency staff, family, teachers, and peers. We analyze the nature and content of these supports and the ways in which the supports influence refugee access and persistence in school. Further, we explore the ways in which technology mediates refugee students' access to and experience of both locally- and globally-situated supports. 
The contributions of this empirical work are both theoretical and practical. From the experiences of refugee children who have been successful in education, we build on Bronfenbrenner's ecological model (1979). In particular, we present a theoretical model of globally-situated, virtual relationships, their connection to locally-situated relationships, and the social capital that accrues through both. The findings are relevant for policy and practice as well, particularly in the promotion of educational opportunities for refugees and other marginalized children, by United Nations or government agencies, non-governmental organizations (NGOs), and communities, including families, teachers, and students themselves. While this work focuses on the experiences of Somali refugees, it has relevance theoretically and practically not only for children in conflict-affected nation-states but also for children experiencing more localized conflict, social instability, and lack of equal educational opportunities who similarly struggle to chart pathways to educational success.

\section{Theoretical and Conceptual Frames: Charting Educational Pathways in Refugee Contexts}

Given processes of flight, most refugees arrive in exile with limited resources. The nature of contemporary conflict, which targets civilians, means those who become refugees are among the most marginalized, economically, politically, and educationally. Outside of their home communities, displaced from their national education systems, and in environments of little human and social capital, refugees generally have few resources and confront great challenges (Harrell-Bond, 1986; Zetter, 2015). In these contexts, how do refugee students chart educational pathways? To create a theoretical framework for understanding the educational pathways of refugees, we draw on concepts of social capital and local/global interactions, and situate associated supports and resources within an ecological systems model.

\section{Supports for Educational Success among Refugees}


Academic support, such as guidance, tutoring, writing support, exam preparation, and course selection, can play an important role in educational persistence and success, particularly for marginalized children and young people. These types of academic support are especially useful when they are embedded within relationships that also provide social support, which includes having people to talk to and feeling part of a group, and emotional support, which includes managing stress, feeling content, self-confident, and encouraged (Lawson \& Lawson, 2013; Roorda, Koomen, Spilt, \& Oort, 2011).

Locally-situated relationships that could provide this academic support are limited in refugee settings, where literacy rates are low (UNHCR \& Global Monitoring Report, 2016) and possibilities for contact with more educationally diverse national populations are limited given the isolation of camps. In marginalized communities, virtual support, mediated by technology, can be as effective and sustainable as face-to-face mentorship (Single \& Single, 2005), provided there is frequent contact (Purcell, 2004) and the nature of that contact feels more like a relationship than a formal program (Spencer, 2007). Could virtual, globally-situated supports enable educational persistence and success for refugees?

The formation of relationships - both face-to-face and virtual - that could provide educational supports to refugee students is importantly informed by literature on social capital. Social capital is the value of relationships and trust among people that enables productive activity (Bourdieu, 1986; Putnam, 2000). Bonding social capital describes social ties within communities that are bounded, for example, by geography or class. The resulting benefits, while tangible, are often limited in scope, especially in marginalized communities. They include, for example, small cash loans, transportation, or emergency childcare. Bridging social capital, on the other hand, enables people to extend their opportunities through social ties built across 
communities, which often span differences of geography or class.

Bridging relationships that connect refugee students to individuals with higher levels of education, for example, might enable refugee students' success in school through connections to a scholarship opportunity, guidance on expectations for academic writing, extra help with complex math, or understanding the "rules of the game" for education. This kind of bridging social capital can be more fruitful than bonding social capital as it extends opportunities, but it is also much more challenging to build and maintain. Bridging relationships are more successful and sustainable when those involved share some characteristics, such as country of origin or gender, even when they also bridge differences, such as education level or class (Higgins, 2001; Putnam, 2000). In this way, relationships can be most effective when they stretch comfort zones and cross some lines of difference, but contain enough commonalities to foster the development of a relationship.

Two possible, little-understood sources of bridging social capital may derive from the unique situation of refugees. These sources of support are globally-situated. We define global not in dichotomy to local, but instead draw on Tsing's concept of "traveling" (2005). This concept focuses our inquiry on interactions and connections among ideas and resources that travel between the refugee camp and other spaces. Tsing helpfully notes that these interactions and connections are often made in fragments, as individuals collect and piece together these ideas and resources from a wide array of sources. She further analyzes how the origins of these traveling relationships disrupt conventional views of resource-flows. They do not, she writes, begin - or end - in "imagined world centers such as New York, Tokyo, or Geneva...” but instead circulate through informal networks with origins and destinations in all geographies (2005, p. 271). We seek to understand if and how refugee students engage in "traveling" through 
globally-situated interactions and connections, and how these processes may foster access to bridging social capital. In this way, while many scholars are concerned with institutions of globalization, we focus here on the globalization of relationships.

The first opportunity for globally-situated social capital is connected to international humanitarian organizations that work in refugee camp contexts. In this case, global resources travel physically to the refugee camp. The United Nations High Commissioner for Refugees (UNHCR) is the organization mandated with the physical, political, and social protection of refugees; with the delivery of humanitarian assistance such as food, shelter, and water; and also with the provision of education. In camps, UNHCR staff members work alongside staff from local and international NGOs. These UNHCR and NGO staff members are national (from the host country) and international (from outside the host country); they are usually highly educated, and their experiences, information, knowledge, and connections travel to the camp with them, bringing globally-situated resources that are different from those already available in the camp. The second possible source of globally-situated social capital involves refugees' connections to people from the same country of origin who have migrated elsewhere, in which case the traveling of resources is virtual. Economic and social ties between diaspora and their countries of origin are substantial (Levitt \& Jaworsky, 2007), including increasingly in conflict settings (Bernal, 2006; Horst, 2006; Lindley, 2009). Yet aside from remittances to pay school fees, the traveling of educational resources, especially in the form of relationships, remains under-studied.

This study explores the ways in which refugee students engage with locally- and globally-situated resources in charting their pathways to education. An ecological systems model, explained below, provides a framework for understanding educational social capital and the ways it may travel to and from refugee camps. 


\section{Refugee Ecosystems: Locally- and Globally-Situated}

In Bronfenbrenner's ecological model of human development, individuals operate within nested systems, including the microsystem (family, peer group, school), the mesosystem (interrelationships between microsystems, such as between parents and school), the exosystem (institutions and practices that affect the individual), the macrosystem (social and cultural norms), and the chronosystem (historical and environmental transitions over time) (Bronfenbrenner, 1979). Armed conflict disrupts an individual's ecosystem, acting as "an ecologic shock of destabilization” (Boothby, 2008, p. 502), separating families and peers; shifting institutional, social, and cultural contexts; and creating a culture of violence that generally interrupts supports for children. Research on refugee children's physical and mental health draws heavily on Bronfenbrenner's model to explain positive and negative developmental outcomes. When resources are compromised within any of the systems, the risk of poor developmental outcomes for children increases. Conversely, when resources are in place across the systems, refugee children can achieve more positive physical and mental health outcomes (see, for example, Betancourt, Meyers-Ohki, Charrow, \& Tol, 2013; Porter \& Haslam, 2005).

When resources are in place across the systems, refugee students may also achieve more positive outcomes in education. We posit that how refugee children and young people rebuild resources across their ecosystems in the face of the "ecological shock" of conflict, flight, and life in refugee camps may be usefully informed by their locally- and globally-situated positions, as described above. This unique situatedness of refugees as related to Bronfenbrenner's model is explored below and summarized in Table 1.

Bronfenbrenner describes microsystems as "a pattern of activities, roles, and interpersonal relations experienced by a developing person in a given face-to-face setting" (1992, 
p. 227). These relationships are uniquely influential as the individual has agency over them and acts to contribute to their construction and maintenance. Local, face-to-face microsystem relationships in a refugee camp context may have different characteristics than in the refugee's country of origin or in nearby national contexts in the host country. For example, given that refugees are geographically isolated in camps in marginalized regions of host countries, they often have limited or no contact with nationals. On the other hand, given migration patterns and diasporic interactions (Horst, 2006), these same refugees may be globally-situated to have virtual connections in other parts of the world. In this way, they may have access to traveling microsystem relationships not initially conceptualized by Bronfenbrenner. While not face-toface, these connections can share similar characteristics of being frequent, influential, and highly personal relationships over which individuals have control (Li \& Lee, 2013; Preece, 2000).

The mesosystem comprises inter-relationships between an individual's microsystems. For children, the mesosystem importantly involves relationships between home, school, and community. These inter-relationships for refugees may be limited. Refugees attend schools that are locally-situated within the national education system of the host country, globally-situated within structures of UNHCR and NGO partners, or a combination of local and global management and oversight (Dryden-Peterson, 2016). Viewed in terms of bridging social capital, refugee families may not share many characteristics on which relationships can easily be built within these unfamiliar educational systems.

The exosystem, which includes institutions and practices that affect the individual but over which the individual has no control, may be similarly bifurcated for refugees, including along locally- and globally-situated dimensions. By fleeing across an international border, refugees enter a foreign nation-state and are subject to its institutions and policies. For example, 
in Kenya, refugees live in geographically isolated settings, lack freedom of movement, and are prohibited from accessing employment outside of refugee camps (Lindley, 2011). Yet refugee education policies and practices are globally-informed, with ideas and resources traveling from outside the camp through globally-situated actors. The lack of resources embedded in the locallysituated exosystem may lie in contrast to what could be viewed as an augmentation of resources in the globally-situated exosystem of educational institutions and staff.

The macrosystem is the social and cultural norms comprised of "belief systems, resources, hazards, life styles, opportunity structures, life course options, and patterns of social interchange" (Bronfenbrenner, 1992, p. 228). For refugees, these macrosystems are informed by belief systems carried with them from countries of origin as well as prevailing attitudes and ideologies in the host country. Given the actors involved in camps, the macrosystem might also be described as globally-situated, reflecting global consensus norms such as a universal right to education expressed in the Convention on the Rights of the Child (CRC). This right to education might be seen as a resource embedded within the globally-situated macrosystem of refugees, although it may also come into conflict with norms in the country of origin or exile, such as nonratification of the CRC by Somalia, or a lack of strong support for girls' attendance in schools.

The chronosystem involves historical and environmental transitions and, unlike the other systems, involves the dimension of time. Bronfenbrenner argues that these transitions over time "alter the existing relation between person and environment" (1992, p. 201). By definition, refugees have experienced a transition of environment, in their displacement in this case from Somalia to Kenya. Malkki describes the importance of the "deterritorialized nation" (1992, p. 35) emphasizing, like Safran, that similar to most diaspora, refugees "retain a collective memory, vision, or myth about their original homeland" (1991, p. 83). Malkki also documents the re- 
territorialization of the nation in exile for Burundian refugees in Tanzania. The ongoing creation, and re-creation, of historical narratives of nation in an evolving environmental context may define the chronosystem for refugees and influence how relationships, both globally- and locallysituated, are constituted and re-constituted.

In examining how refugee students chart successful pathways through education, this study explores the locally- and globally-situated nature of refugee students' ecosystems. Rather than a reified nested system, our work draws attention to the ways in which refugee students engage in the kind of "traveling" Tsing describes, locating resources across these systems, and to the kinds of social capital that accrue through resulting relationships. [Table 1 about here]

\section{Context of the Study}

\section{Somali Refugees and the Dadaab Camps of Kenya}

Since the 1970s, Somalia has experienced ongoing instability, state collapse, and protracted armed conflict. The fall of Siad Barre's regime in 1991 marked the beginning of almost three decades during which Somalia has earned the label of the world's "most failed state" (Fund for Peace, 2014). Ninety percent of all schools were destroyed and literacy rates fell to less than 38 percent, such that 4.5 million people were unable to read or write in any language (Barakat et al., 2014, p. 8). Drought and famine intensified the impact of conflict in Somalia, creating what Hyndman calls a "dual disaster" (2011).

This dual disaster in Somalia has generated one of the largest movements of refugees and internally displaced people in the last century. The total population of Somalia is 10.8 million people (World Bank, 2015). Between 1 and 1.5 million Somalis have been displaced outside of Somalia and live in diaspora around the world; an additional 1.5 million are internally displaced within the borders of Somalia (Hammond et al., 2011, p. 12). The diaspora is both near and wide 
(Van Hear, 2009, p. 181), the latter concentrated in the United Kingdom (pop. 95,000-250,000), the United States (pop. 100,000), and Canada (70,000-100,000); and the former, much larger diaspora concentrated in Kenya (pop. 415,000) and Ethiopia (pop. 250,000) (Hammond et al., 2011; UNHCR, 2016). Somali diasporas are, in general, very active and well-connected to each other and to the country of origin (Horst, 2006). Well-documented among these connections are monetary remittances; the Somali diaspora sends US $\$ 1.3-2$ billion a year in private remittances and an additional US\$130-200 million in humanitarian and development assistance (Hammond et al., 2011), amounts which exceed the annual GDP of Somalia (UN Data, 2014).

The largest population of Somalis in exile is in Kenya, where Somali refugees live in both urban areas around Nairobi and in rural refugee camps. The vast majority of them - almost 350,000 at the time of writing - live in the Dadaab camps. Built in 1991 to accommodate 90,000 refugees, the Dadaab camps are among the oldest refugee camps globally and host the largest concentration of refugees in the world. The UNHCR manages the camps, hiring NGOs to implement direct services related to shelter, water, health, and education, among others. Aid flows to Dadaab are chronically insufficient, with many refugees unable to meet their daily needs. Further, the future of the camps - and of Somali refugees in Kenya - is in constant flux, with the Kenyan government expressing increased security concerns over terrorism connected to al-Shabaab, an al-Qaeda affiliate headquartered in Somalia (UNHCR, 2017).

\section{Education and Information and Communications Technology (ICTs) in the Dadaab Camps}

The international NGO CARE set up the first schools for refugees in the Dadaab camps in 1993, with funding from UNHCR. At that time, international actors were motivated to offer only primary education, as education beyond that level was considered an incentive for refugees to avoid return to Somalia (Hyndman, 2000). By 1997, conflict conditions in Somalia made clear 
that return was not likely in any foreseeable future. Soon thereafter came the first possibilities for post-primary education for refugees. In 1999, 10 boys sat and passed the exam for the Kenyan Certificate of Primary Education (KCPE) and were given scholarships to a regional Kenyan secondary school outside of the camps (Marangu, Gitome, \& Njogu, 2011).

Later that same year, UNHCR and CARE established three secondary schools in the camps and enrolled 215 students; refugee community members established three additional schools in 2008, at which time there were 2,077 students enrolled in secondary school (Marangu et al., 2011). In 2014, there were seven secondary schools in the Dadaab camps, yet net enrolment ratios at secondary level were only 2.3 percent. Higher education has been even more limited, including a few scholarships offered each year by World University Service of Canada and the Albert Einstein German Academic Refugee Initiative (DAFI) Program, and the new Borderless Higher Education for Refugees (BHER), which opened 200 places in 2014 for a blended online and face-to-face program. Education in the Dadaab camps is guided by the UNHCR Global Education Strategy, 2012-2016 (UNHCR, 2012), and by the Joint Strategy for Education in Dadaab, 2012-2015 (UNHCR \& UNICEF, 2011).

Information and Communications Technologies (ICTs) are increasingly available in the Dadaab camps, and the most prominent use of ICTs in the camps is the mobile phone. Mobile phone usage in Kenya has grown exponentially over the past decade, including in Dadaab. A survey of students who completed secondary school and were currently enrolled in the BHER program $(n=89)$ indicated that 78 percent had mobile devices (Orgocka \& Saita, 2014).

\section{Methodology}

In seeking to understand how refugees navigate schooling and achieve educational success, we have chosen to analyze the experiences of a group of students who have been 
successful. This decision was purposeful. More is understood about the factors that inhibit school success for extremely marginalized populations than is understood about strategies that enable success (Lewin, 2009). Existing research on the educational trajectories of refugees, and the experiences of refugees in Dadaab and Kenya broadly, focuses primarily on the failure of systems and lack of opportunities (Dryden-Peterson, 2016; Horst, 2006; Lindley, 2011; Mendenhall, et al, 2015). We frame this investigation with a focus on opportunities and enabling factors with the aim of understanding why and how some students are successful. Despite the "ecological shock" of conflict and displacement, where across their ecosystems do refugee students locate and access supports, and what is the nature and content of these supports?

We use two different methods in order to generate complementary sources of data: indepth semi-structured interviews $(n=21)$ and surveys $(n=248)$. The population of interest in both cases is Somali refugees who completed secondary education. The methods complement each other in both substance and sequence. Vis-à-vis substance, the study aims to build theory on supports for educational success among refugees. For this purpose, we worked within a constructivist paradigm, seeking to document and understand, through qualitative interviews, a complexity of views about these new phenomena (see, among many, Maxwell, 2013). Our survey allowed a degree of pragmatism, in gathering data that could provide an albeit imperfect understanding of the scope of these nascent phenomena. We view this pragmatism as an ethical imperative in research in conflict settings (see also, Wood, 2006). Vis-à-vis sequence, we integrated the methods (Johnson \& Onwuegbuzie, 2004, p. 20) both in the design phase, in which the interviews shaped the content of the survey (sequential design), and in analysis of the data, in which surveys and interviews informed each other (concurrent design) (Creswell, 2014). Unlike most studies in this field (Burde, Kapit, Wahl, Guven, \& Skarpeteig, 2016), this 
research is not commissioned. We relied on relationships with both UNHCR and Windle Trust Kenya, an NGO working on education in Dadaab, in order to access the militarized setting of the camps, and to arrange interviews and transport, given restrictions on our movement, including travel in armed convoys and limited to gated and guarded compounds. We nevertheless remained independent in our research design, data collection, analysis, and funding. The research questions align with a long-term research agenda on refugee education; however, we did incorporate certain questions of interest to UNHCR and Windle Trust in our survey and interview guides with the aim of reciprocity and in line with our commitments to engaged scholarship that can usefully inform practice and policy. We were consistently aware, both in data collection and analysis, of our positions as outsiders in Dadaab, marked by the security infrastructure required, our different racial backgrounds, and our language proficiencies, among other factors. We attempted to create spaces to connect with our interview participants, along lines of educational pursuits and often in our roles as teachers, and to explicitly invite them to challenge our assumptions and clarify our misconceptions. Our analytic processes also incorporated on-going reflection on the ways our identities and experiences were shaping our views of the data. The research was approved by the Harvard University Institutional Review Board and what was then called the Republic of Kenya National Council for Science and Technology (now the National Commission for Science, Technology and Innovation).

\section{Data Collection}

We conducted in-depth semi-structured interviews with 21 Somali students who completed secondary school in Dadaab refugee camps, 14 males and 7 females. The interviews sought to elicit data on the general life history of the participant with a focus on educational trajectories and also asked specifically about educational supports received and given (e.g., Tell 
me about the people who have helped you be successful in your education); current work (e.g., How has the support of [people and institutions] mattered to you in your education/ in your current work?); transnational connections (e.g., Where geographically is the space you find best to pursue your education/do your work?); technology use (e.g, What kinds of support do you seek/ provide through online/virtual connections?); identity (e.g., How does your work in Dadaab shape your life in Kenya?); and gender-based experiences (e.g., Who do girls/ women turn to for educational support?), this latter category driven by well-documented inequalities for Somali refugee girls in accessing educational opportunities (Buck \& Silver, 2012; UNHCR, 2014). We conducted the interviews in English, after asking participants in which language they felt comfortable for the interview. We nevertheless recognize this limitation; while all interview participants had been educated through high school graduation in English and had passed English requirements to enroll in tertiary education, English was not the language spoken at home by any of our participants. All interviews were audio-recorded and lasted approximately one and a half hours. We also, with permission from the interview participants, took fieldnotes on pre- and post-interview conversations and the setting. At the time of the interviews, 12 of the participants continued to live in Dadaab, 3 had moved to Nairobi to pursue higher education, and 6 had been resettled to Canada to pursue higher education (see Table 2). [Table 2 about here] Our sample of research participants evolved through multiple networks of contact, including relationships with UNHCR and Windle Trust, as well as connections with former refugee students, since resettled, and an on-going snowball strategy. All but one of our interview participants, were or had been (before resettlement) employed by an NGO, the highest level of employment in the camps for secondary school graduates. The interview participants fitted our 
sample of interest, being the most successful secondary school graduates, along metrics of scores on final exams and securing employment after graduation.

These in-depth interviews were complemented by an online survey aimed at determining, in a descriptive and exploratory way, patterns of educational supports for Somalis in a broader population. The survey included questions on types of support (e.g., Do you seek academic support (guidance, tutoring, writing support, exam preparation, course selection) from online/virtual connections (not in person)?); sources of that support (e.g., From whom do you seek online/virtual academic support?); global connections (e.g., Do you communicate with Somalis living in the Dadaab refugee camps of Kenya?, followed up with questions of with whom and how); and access to ICTs (e.g, How often do you access the Internet?); most of the questions were closed, a few were open-response. We developed the survey following the process outlined by Gehlbach and Brinkworth (2011), including a comprehensive literature review, consultation with Somali university students, and two rounds of cognitive pre-testing.

This survey was limited to Somalis who were over the age of 18 and had completed secondary school. We distributed the survey to every Somali-serving organization we could locate online in the United States, Canada, the United Kingdom, Sweden, Ireland, and the United Arab Emirates ( $\mathrm{n}=87)$; through social media, particularly Facebook groups $(\mathrm{n}=34)$; on Somalirelated radio broadcasts $(\mathrm{n}=18)$; as well as via listservs $(\mathrm{n}=8)$ and personal contacts for Somali $(\mathrm{n}=106)$ and non-Somali $(\mathrm{n}=133)$ individuals who do related work. Each contact was sent one initial email and one reminder email, with a request to share through their networks. The survey was open from February 25 to June 18, 2014. We analyze here the 248 surveys that were complete and from unique IP addresses. 
Our survey reached Somalis who were geographically disbursed, primarily in the United States ( 35 percent), Canada (17 percent), Kenya (14 percent), Somalia (9 percent), and the United Kingdom (7 percent), broadly mimicking overall global patterns of Somali diaspora with secondary school education, although underrepresenting Somalis in the UK. Sixty four percent of the respondents were male, and 36 percent female, likely an indication of the continued gender disparity in access to education and technology even in diaspora (Buck \& Silver, 2012). The vast majority of respondents were between the ages of 20 and 40 ( 82 percent). While the requirement for survey completion was secondary school graduation, 81 percent had at least some postsecondary education, a likely artifact of who is connected to the networks we accessed and who can easily access the Internet to complete an online survey in English. Seventy nine percent of the respondents were born in Somalia. Just over half of the respondents had lived in a refugee camp, with 70 percent of those having lived in Dadaab ( $\mathrm{n}=88)$, allowing for a comparison among those who had and had not lived in camp settings (see Table 3). [Table 3 about here]

Our survey had a target population with two characteristics recognized as being among the most challenging to reach: the population is mobile and marginalized (MacDonald, 2015; Vigneswaran \& Quirk, 2012). An online survey with multiple entry points provided the advantage of reaching members of this target population who are not reachable in other more geographically-circumscribed way (Crush et al., 2012) and who are connected to each other in highly-networked ways (Friberg \& Horst, 2014; Massey, 1999). However, the sampling frame remains ill-defined. Given the limitations, we present only exploratory and descriptive analyses of the survey data, which importantly informed our in-depth qualitative data analysis.

\section{Data Analysis}


Analysis of the survey results was descriptive and conducted using the statistical software package Stata 13 in three stages. We first developed a set of summary statistics for each of the key variables. As a second step, we analyzed the data across a set of subcategories. We were particularly interested in considering differences in the survey results by sex, given existing inequalities (see also Dahya \& Dryden-Peterson, 2016); and residence (or not) in a refugee camp and length of stay in a refugee camp, as connected to our questions about supports for education that refugees in camps access. Third, we considered the results based on the type of virtual support prioritized by the respondent. We looked separately at the data from respondents who indicated they received virtual academic support $(\mathrm{n}=87)$. Participants were asked an additional series of questions depending on which type of support they prioritized (social support, emotional support, advice on family matters, career guidance, and spiritual/religious support), resulting in different sample sizes for each of these sub-analyses. The survey allowed participants to skip questions they did not wish to answer, so sample sizes vary.

Analysis of the interview data was on-going and iterative. Immediately following each interview, we listened to the audio recording and wrote notes on the participant's main ideas, including relevant verbatim quotes and our initial thinking about the ideas. Through this process, we wrote narrative profiles for each interview participant (Seidman, 2006), which allowed us to reconnect with data that were still connected to the participant's voice, to examine the data from each interview participant as a separate unit of analysis, and to identify initial emerging themes that informed later interviews and the survey design. After completion of all interviews, the audio recordings were transcribed verbatim; we used the qualitative data analysis software Atlas.ti to code these transcripts. We began with an initial list of etic codes generated from the literature; for example, within the code family of supports, we included peer-to-peer, 
scholarships, family, among others, with separate codes for face-to-face and virtual interactions. Two of the authors independently coded the same three transcripts with these etic codes, adding emic codes as necessary through this process. Emerging emic codes deepened our understanding of the nature of face-to-face and virtual relationships and included, for example, content of virtual communications, serving as a role model, interaction with Kenyan society (individuals and institutions), among others. We then discussed each instance where there was a difference in coding to come to consensus on the code to be applied. The researchers agreed on a final codebook, which included definitions, exclusions, and examples for each code. One researcher coded the interviews from Dadaab and one researcher coded the interviews from Nairobi and Canada. Each researcher reviewed the other's coding and in any instance where there was a discrepancy, it was discussed until a consensus was reached (see Smagorinsky, 2008 who calls this process "collaborative coding"). We wrote analytic memos on each code as a mechanism to synthesize analysis across interview participants (George \& Bennett, 2005). Through this memoing process and analysis across codes, the applicability to Bronfenbrenner's ecological systems model emerged.

\section{Findings}

In this section, we present and interpret the study's findings in three steps. First, we present a narrative of one refugee student - Abshir - focusing on the multiple supports, and their ecological sources, that he identified as contributing to his educational success. We begin our findings with this narrative in order to demonstrate holistically the locally- and globally-situated supports of one individual before analyzing separately these supports comparatively across the whole dataset. We chose Abshir, as the supports he described are illustrative of the kinds of supports that were salient to refugee students' educational success across our dataset. We return 
to this narrative in the Discussion section to examine points where Abshir's educational trajectory might diverge in the absence of certain kinds of supports. Second, we present the results of the survey of Somali secondary school graduates to begin defining the types, sources, and channels of support that refugee students who have experienced educational success identified as important. Third, we explore the nature of these supports through interview data. Echoing Bronfenbrenner, we move purposefully from examining the role of globally-situated institutions and actors to examining locally-situated relationships with and among self, family, teachers, and peers. For these latter relationships, we identify and analyze the creation of globally- and locally-situated social capital.

\section{Navigating for School Success: Abshir}

Abshir was born in 1991 in central Somalia, just as the regime of Major General Siad Barre fell and the country was engulfed in a conflict that, as it turns out, would last his entire childhood and beyond. Through this childhood, he described having "no parent to guide" him, as his parents were killed in the war. As the conflict in Somalia intensified, his older sister carried him - just a baby at the time - to Dadaab, set up just a year before their arrival. Abshir would watch the camps grow from their capacity of 90,000 refugees to reach their highest levels of more than 463,000 in 2012 (UNHCR, 2015).

Abshir began Standard 1, the first level of primary school, in Dadaab at an appropriate age for the class. "The agencies have supported us very well," he said. He described how, as he got older, classrooms were constructed, distinct from the trees under which he used to learn. These classrooms were crowded, however, with not enough schools for the many refugees who continued to arrive in the camps. Abshir recalled that his classes were often filled with 70 children or more and, even still, there was not space for all children to attend, especially girls. 
His sister never had the chance to go to school, marginalized by what Abshir labeled as a "community belief" that "there is no need [for girls] to go to school. Even if she learns, her knowledge will be wasted...[as] she will just stay home, she will care for the children."

For children like Abshir who did have the chance to go to school, education was of limited quality. Abshir did not believe that his teachers could "teach you properly." He said, "we used to have only our teachers who are just like us...They were not trained...my [social studies] teacher, he was a Standard 8 failure." Abshir was the only one in his class to pass the primary school leaving exam. By age 20, Abshir was a Form 4 graduate, holding a Kenyan Certificate of Secondary Education (KSCE). He was also a primary school teacher employed by the international NGO CARE and about to begin studying for a bachelor's degree with the BHER program in Dadaab. How did Abshir navigate this successful pathway through education?

"There was a teacher, Kablan" Abshir explained. "He used to encourage me. He used to push me all the time." This teacher had lost his parents, like Abshir, and "he used to tell me, 'Your parents have passed away...So you study so... you have a good future. Tomorrow, you may become even a President." Abshir recounted that Kablan would take a loan to buy books for him, noting that he would not have been able to study without them. Kablan was since resettled to Canada, with a scholarship to pursue higher education. He remains connected to Abshir on Facebook, and this former teacher is one of Abshir's biggest supports in his education. On the day that the KCSE results were announced, Kablan picked up the phone, in Canada, and called Abshir, in Dadaab, to find out his score.

Sources of income were terribly hard to come by in Dadaab, and yet Abshir needed money for books and a uniform. Ironically, it was Abshir's sister who provided the instrumental support that enabled him to stay in school when costs became prohibitive. Abshir's sister and her 
husband made money by carrying goods from the market in a wheelbarrow and they gave it to Abshir for school. Not all refugee students had this financial support. When the costs of education became prohibitive for one of Abshir's friends and former classmates, he decided to return to Somalia. In communicating through the Nimbuzz $\mathrm{App}^{2}$ on their smartphones, the friend told Abshir, "[I do not] do anything. I just stay here...[while other classmates have] passed to the next degree of letters."

Even friends who were able to continue their education were often sitting around doing nothing, Abshir found. He explained that some who finished secondary school chewed miraa, plant leaves with an amphetamine-like affect; others would sit in local community-based film screening rooms all day. The experiences of his peers left Abshir questioning the purposes of persisting through all of the challenges to complete his education. What were the benefits? Abshir described the lack of opportunities to pursue studies beyond secondary school; "we cannot proceed our education further," he said, "cannot go to other parts of the country because [we] don't have any kind of ID." Again, Abshir's teacher, Kablan, despite his geographic distance, remained a persistent role model for Abshir in the presence of so many pathways away from school success. With this support, Abshir did not drop out. When Abshir got news of his acceptance into a bachelor's degree program, Kablan and his sister were the people he told first.

\section{Defining Supports and their Sources: Survey Results}

In Abshir's pathway through education, a number of mechanisms of support are evident. These supports are diverse in their nature (e.g., academic, financial, emotional) and in their source (e.g., family members, teachers, peers, NGOs), drawing on both the locally- and globallysituated dimensions of his ecosystem. Through our survey of Somali secondary school graduates, we sought to understand the various types of supports that refugee students who have 
experienced educational success identified as important to their school success, from whom they received those supports, and through what mechanisms this support was provided. We term virtual any non-face-to-face forms of support.

Survey respondents $(n=248)$ converged around traditional academic support - such as guidance, tutoring, writing support, exam preparation, course selection - as important to their success in education. Seventy percent of respondents noted that this support was "extremely important" or "very important," true across men and women in the sample. The experience of living in a refugee camp augmented the salience of academic support, when compared to the sample as a whole, with 81 percent of those who had lived for an extended time in refugee camps placing it in these categories of importance. Women who lived in a refugee camp prioritized academic support even more highly in their academic success, with 89 percent thus ranking it.

The most common sources of academic support were within the microsystem: teachers, friends, and family members. Approximately half of the survey respondents received academic support from each of these three sources, consistent across the full sample and the sub-samples of respondents who had lived in refugee camps and when examining women alone. Most sources of support were locally-situated, with 55 percent of respondents noting that they did not receive any academic support from virtual connections, relying instead on in-person academic support. Such was true for 47 percent who had lived in a refugee camp and 57 percent of women.

Of the 45 percent of respondents who did receive virtual academic support, 69 percent noted that their virtual academic support was locally-situated. It came from people living in their same geographic location - "in the place where you live" rather than "in a different part of the country where you live" or outside of that country - indicating the likelihood, though not the certainty, of virtual connections building from pre-existing face-to-face relationships. The local 
creation of this support was even further magnified for respondents who had lived in refugee camps and for women, with 75 and 81 percent respectively responding that their virtual connections were with community members who were local to their geographic location. At the same time, globally-situated virtual connections outside the place where respondents lived were not unimportant. Teachers, friends, and student peers were the most common sources of this virtual academic support, more so than family members (see Table 4). Email and phone were the most cited channels of globally-situated academic support, yet text messaging and Facebook were also important (see Table 5). The majority of respondents received this virtual academic support more than weekly. [Tables 4, 5 about here]

Respondents prioritized career guidance, social support, and emotional support as the other virtual supports most critical to their educational success. Thirty percent of respondents ranked career guidance as most important, 22 percent ranked social support (such as having friends you can talk to and feeling part of a group), and 19 percent ranked emotional support (such as managing stress, feeling content, self-confidence, encouragement); supports such as advice on family matters, spiritual guidance, and other kinds were ranked to a far lesser extent. In the full sample, career guidance was consistently most important across both men and women who had lived in refugee camps. The relative importance of career guidance for women and men in camp settings could stem from the lack of career opportunities and especially restricted options for women. In the full sample, however, women prioritized social (24 percent) and emotional (25 percent) support more frequently over career guidance, perhaps because, as some of the very few educated Somali women, they were physically isolated from well-established community supports (see Table 6). [Table 6 about here] 
Fifty three percent of respondents received career guidance virtually but from locallysituated people, primarily friends and teachers. Interestingly, 43 percent received guidance from people living in a different part of the same country in which they lived, and 45 percent among those in refugee camps, perhaps indicating the national context-specific nature of this kind of support, which is dependent on knowledge and navigation of the exosystem. Likely reflecting gender differences in access to technology, women in the sample used virtual mechanisms for career guidance far less than men.

Sources of virtual social and emotional support were similar, with friends and family prioritized by a vast majority of all survey respondents, both men and women. Of note is that in our sample, women living in refugee camps received virtual emotional support overwhelmingly from family (75 percent) and friends (100 percent), and far less from teachers ( 25 percent) than their male peers (64 percent). More so than all of the other types of support, male and female respondents received virtual social and emotional support that was locally-situated, from people who lived in the same geographic location as them. An overwhelming majority of respondents received virtual social and emotional support at least weekly, through a variety of mechanisms: phone (92 percent), text messaging, email, and Facebook (62 percent each).

The importance of locally-situated support was clear across all types of support: inperson and virtual interactions with people who live in the same geographic location as the respondent were the most common ways of receiving support for school success. The results echo research suggesting that virtual social networks often stem from, and are strengthened by, face-to-face connections (Ellison, Steinfeld, \& Lampe, 2007). The combination of virtual and face-to-face supports we see in this survey data lends credence to the idea that types of support are not mutually exclusive but instead may be additive. Further, in a highly mobile population, 
locally-situated supports can transform into globally-situated ones. Our interview data sheds light on this process - the traveling of relationships and the technology that mediates them - as well as the types of social capital these relationships can create.

\section{Nature of Supports: In-depth Interview Findings}

Globally-situated exo- and macrosystems: Access to education. Abshir was clear that the structures international agencies provided for education in Dadaab were a foundation upon which he built his pathway through education. All interview participants echoed the notion that education was a gift bestowed on them by UNHCR and its NGO partners. In this, Abshir felt himself to be globally-situated; as he described it, the "world has assisted us." Abas - who also fled Somalia as a young child and pursued his entire education in Dadaab - noted that international organizations "paid for my free primary education" and "facilitated my high school education." They supplied materials needed for school that, according to Abas, made school life easier in a context when home life was very hard. Abroon chronicled his life in terms of the development of educational programs in Dadaab. First, upon his arrival in the camps, there was no infrastructure and people were teaching and learning outside, under trees, and writing in the soil. Later, he was given limited resources, like notebooks split in half to share between children. Given this ability to continue learning, Abroon noted, "I stopped the plan of going back to Somalia, and I studied from there [Dadaab] under the trees." When a Norwegian agency came, "they built two rooms" and, he said, "from there I completed my primary education."

The structures for refugee education created and augmented over time by UNHCR in collaboration with its NGO partners and with refugee community groups provided the possibility that children in Dadaab could attend school. Yet as Abshir noted, he was the only one in his primary school class to pass the KCPE. All of the interview participants attributed part of their 
educational success to UNHCR and NGO staff members who helped them to develop globallysituated microsystems. For example, students who had been awarded scholarships felt supported by two staff members from Windle Trust, who were physically-based in Dadaab and "who helped me a lot for advice," as Idris said. Relationships with these staff members were motivators for students in Dadaab, served as deterrents to dropping out and, through information and guidance, created opportunities for further study.

In Dadaab, resources embedded in macro- and exosystems made access to education possible, but it was the related locally- and globally-situated microsystem relationships that served as enablers to persist and succeed in graduating from secondary school. It is to these relationships that we now turn.

\section{Locally-situated microsystem: Self and family as inspiration and "backbone." All of} the students perceived the inspiration they found within themselves to work hard, seize every opportunity, and maintain that dedication even in the face of challenges as inextricably linked to the support of their families. Haboon, who completed her high school education in Dadaab and took up a scholarship in Canada in 2013 said, echoing the survey findings, "if your family doesn't support you...there is no way you can go to school." The hope and encouragement that parents, particularly mothers, provided to students were unparalleled. Said Abas, "it was my mother alone. It was her alone...It was my mother who went through a lot with me and my other siblings... She did everything you will have expected a living organism to do for me, and I don't think someone in the future can try to do something like that of similar, the way she did for me." Sacad was "mobilized" by his mother and, for Abroon, his mother gave him "courage."

Mothers played this supportive role in children's educational success despite often not accessing school themselves. Abukaar described his mother as the "backbone of my success." 
Yet he said, "she can't teach me anything because she's illiterate, [but] she used to encourage me to read and strive more so that I succeed." Kahaa noted similarly, "the only support [my parents] have is only to advise me, because they are ignorant. They don't have education."

Family members also provided critical financial assistance to students and undertook household duties to enable the students to focus on their schoolwork. Fourteen students described their mothers selling vegetables in the market, or doing other jobs, to make enough income to pay for school supplies. Mansoor's father pushed a wheelbarrow, transporting goods for others, and "the amount he gets is what we have used to improve our study, for buying for us pens, books," he said. Mansoor's father also created the conditions under which his children could be successful in school, constructing for them "another small house, far away from the homes [where they could study], because mostly we had distraction from noises of small children."

Mothers also undertook cooking and cleaning duties to enable their children to study. Abroon's mother "used to cook for me food at home. Maybe early in the morning, at 5:00am, the food is already cooked. I go pray, I eat my food, I go to school.” All of the girls, however, described having as many household duties as if they had not been studying, but recognized the support of their mothers in two specific ways. Haboon said that "some mothers used to send their daughters to work for another family, get a wage...but...my mother never told me to do that." Hodon described coming home from school to cook and wash her siblings' clothes before sitting down to study "up to 12:00am." Her mother supported her, though, by "not condemning" her if she was not able to finish the housework. Expectations for girls to complete domestic work consistently emerged from the research participants as a barrier to education, yet family members were enablers, taking on household duties, ensuring their children were fed and clothed; 
sometimes, especially for girls, a family enabled by not standing in the student's way (on gender roles, see also Dahya \& Dryden-Peterson, 2016).

Expanding the mesosystem: Teachers as traveling social capital. Overall, 16 of the 21 interview participants identified teachers as providing support to their education. Teachers provided two main types of support: encouragement and academic help. The ability of teachers to provide this support depended upon the relationships teachers and students were able to develop. These relationships reflected the locally- and globally-situated dynamics of the refugee camp. In particular, interview participants universally described the importance of refugee teachers from the local camp community in fostering close relationships with students, as compared to the predominantly male, Kenyan teachers from outside the camp (on the role of refugee teachers, see also Dryden-Peterson, 2017). Hodan described how she benefited from the refugee teachers, who themselves had just finished school: "if I cannot just understand from the [Kenyan] teacher, I usually go to them [the refugee teachers].” Salim explained that he trusted his refugee teachers more than his Kenyan teachers "because I can tell them everything and they will understand and the fact that they can explain to me...combination of Somali, English and everything, how I understand."

Harun, studying in Canada on a WUSC scholarship, recalled a very positive relationship with his teachers in Dadaab. His teachers, he said, "really motivate you, and they teach us, and then they keep saying that you guys should work hard - hard so that you just find the opportunity to get a scholarship, and then find yourself in the very good place of studying." He explained the teachers were "really a motivating factor for every student." Haboon expressed surprise that some of her teachers cared enough to notice when things were not going well for her. "When they see I'm not doing well this time, some of them used to call me, 'Haboon, what's wrong? 
What's the problem?'" They combined this interest with encouragement: one teacher used to say, “"Haboon, you...can perform better. Try it."” Anwar described the specific encouragement his physics teacher provided: "He always helped me, like I remember...I applied several times for this DAFI scholarship, and I was often left [not awarded the scholarship], so I used him to give me the courage - [he would say] 'Anwar proceed, go for it. Don’t just lose courage'.”

Anwar explained that at the time he studied in Dadaab, before he began university courses in Nairobi in 2009, all they had were "the textbooks and what the teacher says." The teachers were thus indispensable supports to his education. Idil further noted the teachers were always available, and Kahaa provided the example that teachers "give me extra classes during the week and Saturdays and Sundays...like practicals [of] chemistry and biology." When Haboon failed in mathematics, she went to a teacher for help, and he served as a resource and tutor. Having “teachers who know me," Haboon noted, was essential to her academic performance: "I had to perform better because it will be shame for you when you perform poorly when you are expected [to do well]." Mansoor described how when teachers were "aware of the condition at home," they "sometimes provided material support, buying materials such as books, papers, and writing materials that were not available from the district with their own funds."

The presence of qualified and experienced teachers in Dadaab shifted over time, with implications for the type of support teachers were able to provide. Until 1997, students followed the Somali curriculum with Somali refugees as their teachers. Refugee education in Kenya at that time was distant from the macro- and exosystem of the host country. After 1997, refugee students began to follow the Kenyan curriculum and to sit for the Kenyan national exams at both primary and secondary levels, coming into more contact with Kenyan institutions and norms. This change also entailed a shift in the language of instruction and examination, from Somali to 
English, which meant that refugee students' success in school then additionally depended on acquiring a new language (see also, Dryden-Peterson, 2015). Concurrent with this shift was new hiring of Kenyan teachers in Dadaab schools. All of our interview participants described the importance of trained teachers - primarily Kenyan - in the camps. Abshir said, "now, the teachers are trained. We have even some teachers who have gone to university and they have attained their degree," pointing to a form of social capital previously unavailable in the camps. Students also noted the increase in books and supplies, part of the globally-situated exosystem of international aid, with the implication that teachers could be more effective under these conditions.

Despite the benefits of qualified Kenyan teachers, refugee teachers, over time, began to provide kinds of support that Kenyan teachers could not. Relationships with refugee teachers did not end with graduation from secondary school, our participants made clear. The nature of these relationships shifted, however, from locally-situated to globally-situated. All but three of our interview participants were connected on Facebook to their former teachers, many of whom had since been resettled to study in Canada or the US, or on scholarships in Nairobi. These virtual connections built on previously existing in-person relationships to stretch across expanses of time and distance. Abas, for example, who moved to Canada, remained in contact with some of his former students. "When we see online each other," he said, "they will seek my advice to reach the WUSC [higher education] goal, to perform well.... just give counseling to students who are waiting to do their final exams, something like this." In this way, social, career, and academic support melded together, as suggested by effective models of academic support. Interview participants in Dadaab universally described the WUSC students studying in Canada as their "role models" who encouraged them and showed them higher education is possible. It 
was in this synthesis of being a trusted role model and being available to provide concrete academic guidance that refugee teachers, who had themselves become educated under similar conditions, provided globally-situated bridging social capital that extended their students' opportunities. Echoing the survey findings, being able to stay connected to these teachers virtually built on the face-to-face connections established through student-teacher relationships in Dadaab.

Expanding the mesosystem: Peers as traveling social capital. In addition to teachers, support from peers resonated across all interview participants as central to their academic success. Interestingly, students defined peers not by age or school cohort but by who had charted a similar educational pathway. In particular, peers were the students who were struggling together to pursue an education as well as those who "came before" and completed high school ahead of our interview participants. With this definition, peers included family members such as brothers, sisters, and cousins; friends and classmates; as well as some teachers. Our interview participants emphasized the ways in which these peers served as role models and provided academic guidance. Peers served these roles from a place of experience, and success; they knew the challenges the students faced and understood possible strategies to overcome them. The ways in which our interview participants engaged peers as role models and for academic guidance were multiple and included informal one-on-one mentoring-like relationships with older students and teachers, the formation of study groups, and on-going connections through social media. These relationships often involved interrelationships among groups of students and teachers, both locally-situated as in face-to-face study groups and globally-situated via online platforms.

Classmates and older students were role models to our interview participants in being proof that one could succeed in education as a refugee in Dadaab and in demonstrating how to 
get there. Haron described the example set by students who had been selected for scholarships. When WUSC students returned to the camps from Canada, she said, "everyone is really motivated" as this student served as a "motivating factor, an agent." Salim, now a WUSC student in Canada himself, said "in the camp what supported me most is...that I saw some students from the camps who made it. So it was definitely possible for me to make it.” In an open-ended response on the survey, one respondent noted: "Seeing other successful role model Somalis has been a great motivation for me... 'if they can do it why not me?' has been my motto.” This kind of inspirational support was often coupled with concrete academic support. Kahaa described an older cousin who was one year ahead of her in school. At the point where the work was getting very challenging and Kahaa thought about dropping out, this older cousin began to come to her home every night to help her understand the concepts.

Study groups were one site of relationship-building and academic guidance. Initially formed in informal ways, the study groups frequently became strong networks of students who supported each other's success. Mandeeq described the formation of a "small working group whereby we advised during night hours" with the goal that, in Mansoor's words, "when two bright students are sitting together, in fact they can benefit from one another." Aaden said, "the best thing is when you are a student you have another student, [then] when you discuss a challenge, you can have a solution." As a teacher, he encouraged his students to form study groups as he had done.

Frequently, these study groups involved recently-graduated students and teachers. In these cases, the study groups were more formal, involving structured lessons or review of previous exams, and the payment of tuition. All of our interview participants credited these extra classes with critical support they needed to succeed. Girls, in particular, noted how these study 
groups gave them structured opportunities to interact with male peers and teachers, which lacked in school settings. Hodan and Dahabo, for example, found the boys to be "bright" and "clever" and to be more open to assisting and explaining concepts in detail than their female peers, for whom the expectation was not to speak up or demonstrate knowledge in mixed-sex settings.

Study groups were not only a face-to-face mechanism of support for educational success; they were also globally-situated, existing virtually through social media. All but one of the interview participants had an Internet-enabled mobile phone on which they accessed Facebook and email. Each of these 20 interview participants did not identify virtual communication with agencies or family members as providing support for education, but they did identify virtual peer support as critical. Reflecting the survey findings, all of the support-building social media connections described by the participants stemmed initially from face-to-face relationships: they were with students from Dadaab who had been resettled outside of the camp, usually for further study. From their places of even greater school success, these virtual connections were embedded with globally-situated social capital, and they "gave me hope," Anwar noted. He said, "it gives me the courage of people that I know that are studying in different places." Mandeeq described how she used Facebook to stay connected to her peers, now studying in Canada, who continue to provide support virtually. She said she opens Facebook every "five minutes" and she communicates with "those boys who were taken to WUSC." They "exchanged ideas" and they told her "the sky is the limit" in terms of her studies.

Via globally-situated social media relationships, participants described being able to receive specific guidance relevant to their education. Abroon found Somali students who give "very good advice on Facebook" and appreciated the ability to have a conversation about that advice, not only to receive it but to engage in dialogue. Hogol described sending her essays to 
her peer who now studies in Canada who reads them and provides feedback virtually. In addition to these one-to-one connections, Salim described a Facebook group of 30 students from Dadaab. The purpose of the group was to share past exam papers and to help each other, using the chat function. The group has become transnational, with 11 members remaining in Dadaab, 6 studying in North America, 7 in East Africa, one in Somalia, and the location of 5 unknown. It includes current students and current teachers. This virtual group is an example of supports for educational success within the mesosystem that span locally- and globally-situated resources.

Chronosystems driven by purpose: Paying it forward and rebuilding Somalia. When asked about their future aspirations, all but two of our interview participants connected the various types of support that enabled their educational trajectories to an overarching purpose of contributing to the reconstruction of Somalia (of the two that did not, one considered himself Kenyan now and the other, resettled to Canada, saw her future work in contributing to education in Dadaab). The inspiration they found within themselves, the encouragement of their families and teachers, the academic guidance of their teachers and peers all stemmed not only from a desire to forward the life possibilities of one individual but to work toward the betterment of community and nation. "One of my educational goals is to become someone, then take part in the reconstruction of Somalia," said Abas. "The only way we can get out of these problems [is] through education. From my primary school, with the help of my parents and how life was, I was just thinking about making a change in the family and to the society. That's how I made it to secondary school." This sense of purpose, which synthesized locally-situated and globallysituated resources with an orientation toward the de-territorialized notion of "home," was a strong support for refugees' educational success.

This belief in the future possibilities of education stemmed from the locally- and 
globally-situated resources that refugee students marshalled within the refugee camps. One of the few benefits of living in a refugee camp was free education. For all of what was lost in living outside one's country of origin, education could be what was gained. This free education was perceived by our interview participants as perhaps the only upside of the destruction of livelihoods they had experienced, both individual and collective. As Haboon put it, "I myself going to school was a contribution to my community." Abroon described a common religious foundation to this way of thinking. He said, "In Islam...if you dig a well and the people are still drawing water from that well, and maybe you plant a tree that is shading all the creatures and human beings, or other animals, even if you die, that river will go for you. It will be endless."

The current state of Somalia was consistently on the minds of interview participants as they pursued education along with the goal of contributing to the reconstruction of what they saw as their home. Anwar, who completed his secondary schooling in Dadaab and was sponsored for a bachelor's degree in Nairobi, expressed his thinking: "Why not...come back to Somalia and add a value on this tree that's growing called Somalia. It's very small and very delicate now." Idiris stated that his "burning issue is to go back to Somali country and construct that collapsed country." The belief in a possible contribution motivated continued studies for the students and, in that way, provided support to their academic success.

Despite the desire to contribute in Somalia, interview participants universally stated they could not return to Somalia until there was peace. Teaching was one of the only work options open to secondary school graduates in the Dadaab camps, and our interview participants described this professional opportunity as both a way to provide an income for their families and also to build toward the future while continuing to live outside of Somalia. Abroon noted that as a teacher he is "making a good contribution to society...because I am building [my students'] 
brains and their future...If you run away with only your shirt and you have the brain, you can work somewhere else and earn a living." Sacad pointed out the direct link he saw between his teaching and the future of Somalia: "the work I am doing now is related to Somalia because if these people [my students], I teach them well, they will be going back, and they will teach there." Students who had been successful in their education in Dadaab were, bit by bit, creating the possibilities for more young people to have the kinds of traveling supports they had had to enable more current and future successes in education.

\section{Discussion}

Refugee children are some of the most educationally marginalized in the world, facing enormous social, political, and economic challenges with few visible resources. In this context, the primary focus of research and practice in refugee education has been on barriers to pursuing education. Through examination of the educational trajectories of refugee students who have been successful in their education, which we defined as graduating from secondary school, this study has aimed to shift the deficit-oriented paradigm, identifying supports that enable refugee students to succeed. In its findings, the study counters two assumptions: first, that refugee young people are solely reliant on globally-situated international humanitarian aid structures for educational success and, second, that few educational supports are accessible in refugee communities, particularly in isolated camp-based settings.

Refugee students in Dadaab described as critical, but not singular, the assistance provided by UNHCR and its NGO partners, particularly in building schools, hiring and paying teachers, and providing scholarships for higher education. Within these support structures, refugee students drew on a complex web of locally- and globally-situated relationships, which spanned the layers of Bronfenbrenner's ecosystem. Many of these relationships enabled access to what 
Tsing would call "traveling" resources, connecting refugee students to the kinds of social capital - academic guidance, support, and encouragement - that they needed to chart pathways through education.

These locally- and globally-situated relationships were particularly essential in moments where students' educational trajectories might have diverged. A re-examination of Abshir's narrative in the context of these findings sheds light on how various locally- and globallysituated relationships mattered to his educational success. Abshir's coming of school age coincided with a shift in the globally-situated exosystem in which UNHCR funded the building of classrooms to accommodate the rapidly expanding population of Dadaab, so he was able to attend school. When he did not have enough money for books, uniforms, and fees, his locallysituated microsystem relationship with his sister and her husband facilitated their financial help. Abshir's relationship with one particularly supportive teacher, Kablan, was initially locallysituated but transformed, through his teacher's migration, into one that was globally-situated and his mesosystem was embedded with new and different kinds of social capital. For example, as he progressed in school, Abshir began to doubt the purpose of education in a country where the exosystem prevented his freedom of movement or the right to work. Yet the virtual connection he maintained with his teacher, whose ideas traveled to Dadaab virtually from a different macrosystem, represented to Abshir expanded possibilities for his future and motivated him to persist, applying to and gaining acceptance into a higher education degree program. Abshir's experience is illustrative of the kinds of locally- and globally-situated relationships with international organization staff, families, teachers, and peers that mattered to refugee students' educational success across our whole dataset. His experience captures the complex locally- and 
globally-situated supports that operate both face-to-face and virtually as enablers of refugee students' success.

This study contributes to the development of a theory of educational supports for refugee students that are both locally- and globally-situated, and it may have relevance for others who are marginalized within nation-states yet with access to traveling resources. For refugees, beyond globally-situated macro- and exosystems that accompany structures of international humanitarian aid, the expansion of personal technology has enabled individuals to build micro- and mesosystem relationships virtually to find globally-situated supports that were unavailable locally. The survey and interview findings suggest an extension of Bronfenbrenner's ecosystems in light of these types of locally- and globally-situated supports, which are both face-to-face and virtual. Following Bronfenbrenner, many of the most important educational supports for refugee students were face-to-face, within micro- and mesosystems. Girls described the support of mothers in lessening the domestic work required of them, to allow them to focus on schoolwork. Both girls and boys relied heavily on self-initiated networks of peers to study together and prepare for exams. Teachers were central supporters, providing encouragement, skills, and knowledge to navigate high-stakes exams and further study. Departing from Bronfenbrenner, refugee students also cultivated micro- and mesosystem relationships that were virtual, spanning geographic space and extending opportunities.

Most of these virtual relationships stemmed from initial face-to-face relationships. Through individual migration, the relationships shifted in nature, in particular in relation to the type of social capital they could provide: refugee students accessed information and academic and social support that was not available in their locally-situated ecosystem. These naturallyoccurring relationships reflect the principles of bonding and bridging social capital. They 
leverage bonding relationships, based on shared characteristics of language, history as a refugee in Dadaab, and Somali origin, as the basis upon which to cultivate bridging relationships across geography and resource context in order to extend opportunities.

Bridging relationships are more challenging to build, what Putnam described as "the toughest to create" (Putnam, 2000, p. 363). Yet when they begin from a place of connection, they are more easily fostered and sustained (Kramer, 2006). Building on bonding relationships, refugee students in Dadaab were able to bridge across certain differences, enabling them to accrue new educational supports. These differences included geographic space (e.g., Canada), type of education (e.g., higher education), gender norms (e.g., sharing household duties), information (e.g., scholarship opportunities), academic skills (e.g., essay writing), and aspirations (e.g., living in a context with the freedom of movement and the right to work). The virtual, globally-situated bridging relationships, which were built on commonalities, stretched but did not break the students' capacity for negotiating these types of difference. For example, Somali women in Canada who were connected to female students in Dadaab had a shared understanding of the gender-based constraints on time and aspirations in Dadaab and were thus able to provide guidance and support that pushed the students to shift gender norms but not so far that they would be ostracized from the community.

Naturally occurring locally- and globally-situated virtual relationships are not the solution for millions of refugee children globally who struggle to chart a pathway to educational success. The survey respondents and interview participants in this study have succeeded in their education in ways that have eluded so many others with similar origins in Somalia and exile experiences in Kenya. Yet the students in this study demonstrate similar "navigational capacities" that have been documented among other marginalized young people globally, 
capacities to overcome obstacles in pursuit of opportunities particularly through the building of relational supports (e.g., Rana, Qin, Bates, Luster, \& Saltarelli, 2011; Swartz, Khalema, Cooper, De Lannoy, \& Segal, 2012; World Bank, 2013).

Moving forward, programs in refugee settings might work to intentionally cultivate these supports that refugee students have identified as central to their success. Many of these supports are locally-situated in the refugee context and could be bolstered by shifting gender norms to facilitate girls balancing schoolwork and domestic work; strengthening family livelihoods so that families can invest in uniforms and books; and facilitating peer-to-peer networks and study groups. Virtual relationships could also be intentionally developed as ways to access academic and social support that is less available in refugee settings. Technology, particularly personal mobile devices, can permeate the isolation of refugee camp contexts, connecting individual refugee students to resources that are in shorter supply in the camps. The virtual connections we document in this study highlight technologically-mediated, globally-situated support for refugees, who are otherwise bounded by the legal restrictions that accompany their refugee status. This study demonstrates existing involvement of Somali diaspora in these types of relationships and points to potential to expand, at low cost, that involvement through purposeful facilitation of virtual relationships.

Virtual connections can provide a mechanism for refugee students to access the locallyand globally-situated supports they need to see "the light at the end of the tunnel" as they pursue pathways through education. These relationships are less contingent on shifting geopolitical dynamics of international aid and security, and they can break down physical isolation to expand opportunities for education. The benefits of expanded opportunities for refugees to be successful in their education accrue not only to the individual, but as collective goods. Refugee students' 
motivation for education is so often tied to a desire to contribute to the peace-building and postconflict reconstruction in their countries of origin. The intersection of locally- and globallysituated supports may enable more refugee students to chart pathways to success in education, which will benefit not only themselves and their communities but may assist in the resolution of the intractable conflicts that engulf their homes.

\section{Notes}

We would like to thank many people who have contributed to this work: the young people in Dadaab, Nairobi, and Canada, for participating in this research and sharing their successes and challenges; Windle Trust and UNHCR for facilitating field research in Dadaab; Kenyatta University, in particular Josephine Gitome; the Borderless Higher Education for Refugees project, in particular Wenona Gilles, Don Dippo, Aida Orgocka, and Emily Antze; Bethany Mulimbi, Sameena Eidoo, Salathiel Ntakirutimana, and Shazia Khan for research assistance; and the Mowana Lab at the Harvard Graduate School of Education for feedback on an earlier draft. The study was generously funded by the Weatherhead Center for International Affairs at Harvard University.

${ }^{1}$ All names of research participants are pseudonyms.

${ }^{2}$ For a detailed description of the distinctions between neighboring host countries and distant resettlement countries as well as the uniquely unfolding situation in Europe, which has characteristics of both, see Dryden-Peterson, 2016.

${ }^{3}$ Nimbuzz is a free mobile application for calling and messaging, aggregating into one instant messaging (IM) accounts like MSN Messenger and Facebook Messenger.

\section{References}


Barakat, B., Shanks, K. (2014). Beyond Fragility: A Conflict and Education Analysis of the Somali Context. New York: UNICEF.

Bernal, V. (2006). Diaspora, cyberspace and political imagination: the Eritrean diaspora online. Global Networks, 6(2), 161-179.

Betancourt, T. S., Meyers-Ohki, S. E., Charrow, A. P., \& Tol, W. A. (2013). Interventions for Children Affected by War: An Ecological Perspective on Psychosocial Support and Mental Health Care. Harvard review of psychiatry, 21(2), 70-91.

Boothby, N. (2008). Political Violence and Development: An Ecologic Approach to Children in War Zones. Child and Adolescent Psychiatric Clinics of North America, 17(3), 497-514.

Bourdieu, P. (1986). The Forms of Capital. In J. G. Richardson (Ed.), Handbook for the Theory and Research for the Sociology of Education (pp. 241-258). New York: Greenwood.

Bronfenbrenner, U. (1979). The ecology of human development : experiments by nature and design. Cambridge: Harvard University Press.

Bronfenbrenner, U. (1992). Ecological systems theory. In R. Vasta (Ed.), Six theories of child development : revised formulations and current issues (pp. 187-249). London: Kingsley.

Buck, P., \& Silver, R. (2012). Educated for change?: Muslim refugee women in the west. Charlotte, N.C.: Information Age Pub.

Burde, D., Kapit, A., Wahl, R. L., Guven, O., \& Skarpeteig, M. I. (2016). Education in Emergencies. Review of Educational Research, online ahead of print.

Creswell, J. W. (2014). Research design : qualitative, quantitative, and mixed methods approaches (4th ed.). Thousand Oaks: SAGE Publications. 
Crush, J., Eberhardt, C., Caesar, M., Chikanda, A., Pendleton, W., \& Hill, A. (2012). Diasporas on the web: new networks, new methodologies. In C. Vargas-Silva (Ed.), Handbook of research methods in migration (pp. 345-365). Northampton, MA: Edward Elgar.

Davies, L. (2004). Education and conflict : complexity and chaos. New York: RoutledgeFalmer.

Dahya, N., \& Dryden-Peterson, S. (2016). Tracing pathways to higher education for refugees: the role of virtual support networks and mobile phones for women in refugee camps. Comparative Education.

Dryden-Peterson, S. (2015). Refugee education in countries of first asylum: Breaking open the black box of pre-resettlement experiences. Theory and Research in Education, 14(2), 118.

Dryden-Peterson, S. (2016). Refugee Education: The Crossroads of Globalization. Educational Researcher, 45(9), 473-482.

Dryden-Peterson, S. (2017). Refugee education: Education for an unknowable future. Curriculum Inquiry, 47(1), 14-24.

Ellison, N. B., Steinfeld, C., \& Lampe, C. (2007). The benefits of Facebook "friends": social capital and college students' use of online social network sites. Journal of Computer Mediated Communication, 12(4), 1143-1168.

Friberg, J. H., \& Horst, C. (2014). RDS and the Structure of Migrant Populations. In G. Tyldum \& L. Johnston (Eds.), Applying respondent driven sampling to migrant populations : lessons from the field (pp. 17-26). New York, NY: Palgrave Macmillan.

Fund for Peace. (2014). The Failed States Index. Washington, DC: Fund For Peace.

Gehlbach, H., \& Brinkworth, M. E. (2011). Measure twice, cut down error: A process for enhancing the validity of survey scales. Review of General Psychology, 15(4), 380-387. 
George, A. L., \& Bennett, A. (2005). Integrating comparative and within-case analysis:

Typology theory Case Studies and Theory Development in the Social Sciences (pp. 263285). Cambridge: MIT Press.

Hammond, L., Awad, M., Dagane, A. I., Hansen, P., Horst, C., Menkhaus, K., \& Obare, L. (2011). Cash and Compassion: The role of the Somali Diaspora in Relief, Development and Peace-building. New York: UNDP.

Harrell-Bond, B. E. (1986). Imposing aid : emergency assistance to refugees. New York: Oxford University Press.

Higgins, M., \& Kram, K. E. . (2001). Reconceptualizing mentoring at work: A developmental network perspective. Academy of Management Review, 26(2), 264-288.

Horst, C. (2006). Transnational Nomads. Oxford: Berghahn.

Hyndman, J. (2000). Managing displacement : refugees and the politics of humanitarianism. Minneapolis: University of Minnesota Press.

Hyndman, J. (2011). Dual disasters : humanitarian aid after the 2004 Tsunami. Sterling, VA: Kumarian Press.

Johnson, R. B., \& Onwuegbuzie, A. J. (2004). Mixed Methods Research: A Research Paradigm Whose Time Has Come. Educational Researcher, 33(7), 14-26.

Kramer, R. M. (2006). Social Identity and Social Capital: The Collective Self at Work. International Public Management Journal, 9(1), 25-45.

Lawson, M. A., \& Lawson, H. A. (2013). New Conceptual Frameworks for Student Engagement Research, Policy, and Practice. Review of Educational Research, 83(3), 432-479.

Levitt, P., \& Jaworsky, B. N. (2007). Transnational Migration Studies: Past Developments and Future Trends. Annual Review of Sociology, 33, 129-156. 
Lewin, K. M. (2009). Access to education in sub-Saharan Africa: patterns, problems and possibilities. Comparative Education, 45(2), 151-174.

Li, H., \& Lee, K. C. (2013). An Interpersonal Relationship Framework for Virtual Community Participation Psychology: From Covert to Overt Process. Social Science Computer Review, 31(6), 703-724.

Lindley, A. (2009). The Early-Morning Phonecall: Remittances from a Refugee Diaspora Perspective. Journal of Ethnic and Migration Studies, 35(8), 1315-1334.

Lindley, A. (2011). Between protracted and a crisis situation: Policy responses to Somali refugees in Kenya. Refugee Survey Quarterly, 1-36.

MacDonald, A. L. (2015). Review of Selected Surveys of Refugee Populations, 2000-2014. Geneva: UNHCR.

Malkki, L. H. (1992). National Geographic: The Rooting of Peoples and the Territorialization of National Identity Among Scholars and Refugees. Cultural Anthropology, 7(1), 24-44.

Marangu, N., Gitome, J., \& Njogu, I. (2011). Background of Education in Dadaab. Paper presented at the Borderless Higher Education for Refugees Workshop, Kampala, Uganda.

Massey, D. S. (1999). International Migration at the Dawn of the Twenty-First Century: The Role of the State. Population and Development Review, 25(2), 303-322.

Maxwell, J. A. (2013). Qualitative research design: an interactive approach (3rd ed.). Thousand Oaks, Calif.: Sage Publications.

Mendenhall, M., Dryden-Peterson, S., Bartlett, L., Ndirangu, L., Imonje, R., Gakunga, D., Gichuhi, L., Nyagah, G., Okoth, O., Tangelder, M. (2015). Quality Education for Refugees in Kenya: Pedagogy in Urban Nairobi and Kakuma Refugee Camp Settings. Journal on Education in Emergencies 1(1): 92-130. 
Orgocka, A., \& Saita, K. (2014). Borderless Higher Education for Refugees: Use of mobile devices among BHER students. Draft report. Toronto: York University.

Porter, M., \& Haslam, N. (2005). Predisplacement and Postdisplacement Factors Associated With Mental Health of Refugees and Internally Displaced Persons: A Meta-analysis. JAMA: Journal of the American Medical Association, 294(5), 602-612.

Preece, J. (2000). Online communities: designing usability, supporting sociability. New York: John Wiley.

Purcell, K. (2004). Making e-mentoring more effective. American Journal of Health Systems and Pharmacy, 61, 284-286.

Putnam, R. D. (2000). Bowling Alone: The Collapse and Renewal of American Community. New York: Simon \& Schuster.

Rana, M., Qin, D. B., Bates, L., Luster, T., \& Saltarelli, A. (2011). Factors Related to Educational Resilience among Sudanese Unaccompanied Minors. Teachers College Record, 113(9), 2080-2114.

Roorda, D. L., Koomen, H. M. Y., Spilt, J. L., \& Oort, F. J. (2011). The Influence of Affective Teacher-Student Relationships on Students' School Engagement and Achievement: A Meta-Analytic Approach. Review of Educational Research, 81(4), 493-529.

Safran, W. (1991). Diaspora in Modern Societies: Myths of Homeland and Return. Diaspora: A Journal of Transnational Studies, 1(1), 83-99.

Seidman, I. (2006). Interviewing as qualitative research. New York: Teachers College Press.

Single, P. B., \& Single, R. M. (2005). E-mentoring for social equity: review of research to inform program development. Mentoring and Tutoring, 13(2), 301-320. 
Smagorinsky, P. (2008). The Method Section as Conceptual Epicenter in Constructing Social Science Research Reports. Written Communication, 25(3), 389-411.

Spencer, R. (2007). "It's Not What I Expected": A Qualitative Study of Youth Mentoring Relationship Failures. Journal of Adolescent Research, 22(4), 331-354.

Swartz, S., Khalema, E., Cooper, A., De Lannoy, A., \& Segal, H. (2012). Navigational Capacities for Youth Employment: A Review of Research, Policies, Frameworks and Methodologies. Cape Town, South Africa: Human Sciences Research Council.

Tsing, A. L. (2005). Friction: an ethnography of global connection. Princeton: Princeton University Press.

UN Data. (2014). World Statistics Pocketbook: Somalia. Retrieved from https://data.un.org

UNESCO. (2015). EFA Global Monitoring Report: Education for All 2000-2015: Achievements and Challenges. Paris: UNESCO.

UNHCR. (2010). Convention and Protocol Relating to the Status of Refugees. Geneva: UNHCR.

UNHCR. (2012). Education Strategy 2012-2016. Geneva: UNHCR.

UNHCR. (2014). Operations Plan: Kenya. Nairobi: UNHCR.

UNHCR. (2015). Kenya Fact Sheet, March 2015. Nairobi: UNHCR.

UNHCR. (2016). Global Trends: Forced Displacement in 2015. Geneva: UNHCR.

UNHCR. (2017). Refugees in the Horn of Africa: Somali Displacement Crisis. Nairobi: UNHCR.

UNHCR, \& Global Monitoring Report. (2016). No more excuses: Provide education to all forcibly displaced people. Paris: UNESCO.

UNHCR, \& UNICEF. (2011). Joint Strategy for Education in Dadaab, 2012-2015. Dadaab, Kenya: UNHCR.

Van Hear, N. (2009). The Rise of Refugee Diasporas. Current History, 179-185. 
Vigneswaran, D., \& Quirk, J. (2012). Quantitative Methodological Dilemmas in Urban Refugee Research: A Case Study of Johannesburg. Journal of Refugee Studies, 26(1), 110-116.

Wood, E. J. (2006). The ethical challenges of field research in conflict zones. Qualitative Sociology, 29(3), 373-386.

World Bank. (2013). Learning and Resilience: The crucial role of social and emotional wellbeing in contexts of adversity. Washington, DC: World Bank.

World Bank. (2015). World DataBank. Washington, DC: World Bank.

Zetter, R. (2015). Protection in Crisis: Forced Migration and Protection in a Global Era. Washington, DC: Global Knowlegde Partnership on Migration and Development. 
Table 1. Refugees' Ecological Systems Framework

\begin{tabular}{|c|c|c|c|}
\hline \multirow[t]{2}{*}{ System } & \multirow[t]{2}{*}{ Bronfenbrenner } & \multicolumn{2}{|c|}{ Refugees } \\
\hline & & Locally-Situated & Globally-Situated \\
\hline Chronosystem & $\begin{array}{l}\text { Historical/environmental } \\
\text { transitions and time, e.g., } \\
\text { displacement }\end{array}$ & $\begin{array}{l}\text { Chronosystem is connected } \\
\text { to collective memory, e.g., of } \\
\text { Somalia }\end{array}$ & $\begin{array}{l}\text { Chronosystem is connected } \\
\text { to deterritorialization, e.g., } \\
\text { collective experience of } \\
\text { displacement, not } \\
\text { geographically bounded }\end{array}$ \\
\hline Macrosystem & $\begin{array}{l}\text { Social and cultural norms, e.g., } \\
\text { right to education for boys and } \\
\text { girls }\end{array}$ & $\begin{array}{l}\text { Macrosystem is informed by } \\
\text { country of origin and host } \\
\text { country, e.g., lack of history } \\
\text { of girls going to school }\end{array}$ & $\begin{array}{l}\text { Macrosystem is informed } \\
\text { by global consensus norms, } \\
\text { e.g., universal right to } \\
\text { education (Convention on } \\
\text { the Rights of the Child) }\end{array}$ \\
\hline Exosystem & $\begin{array}{l}\text { Institutions and practices that } \\
\text { affect the individual but over } \\
\text { which individual has no control, } \\
\text { e.g., media, parental } \\
\text { employment }\end{array}$ & $\begin{array}{l}\text { Exosystem is part of a } \\
\text { foreign nation-state, e.g., } \\
\text { laws in Kenya that isolate } \\
\text { refugees geographically, } \\
\text { prohibit refugee employment } \\
\text { and freedom of movement }\end{array}$ & $\begin{array}{l}\text { Exosystem is part of a } \\
\text { global system of } \\
\text { international humanitarian } \\
\text { aid, e.g., education } \\
\text { governed by UNHCR } \\
\text { standards }\end{array}$ \\
\hline Mesosystem & $\begin{array}{l}\text { Inter-relationships between } \\
\text { microsystems, e.g., school- } \\
\text { family relationships }\end{array}$ & $\begin{array}{l}\text { Mesosystem involves an } \\
\text { unfamiliar education system, } \\
\text { e.g., national system of } \\
\text { Kenya }\end{array}$ & $\begin{array}{l}\text { Mesosystem involves an } \\
\text { unfamiliar education } \\
\text { system, e.g., UNHCR- and } \\
\text { NGO oversight }\end{array}$ \\
\hline Microsystem & $\begin{array}{l}\text { Inter-personal relationships in } \\
\text { which individual has agency, } \\
\text { e.g., with teachers, peers, family } \\
\text { members, other community } \\
\text { members }\end{array}$ & $\begin{array}{l}\text { Microsystem relationships } \\
\text { mediated by geographic } \\
\text { isolation, e.g., separated from } \\
\text { family members, lack of } \\
\text { contact with national peers }\end{array}$ & $\begin{array}{l}\text { Microsystem relationships } \\
\text { mediated by technology } \\
\text { and extend to global actors, } \\
\text { e.g., Somali peers in } \\
\text { Canada via ICTs; } \\
\text { international aid workers }\end{array}$ \\
\hline
\end{tabular}


Table 2. Characteristics of Interview Participants $(n=21)$

\begin{tabular}{l|c|c|c|c|c|c|c}
\hline & $\begin{array}{c}\text { Country of } \\
\text { origin }\end{array}$ & $\begin{array}{c}\text { Location of Primary/ } \\
\text { Secondary Education }\end{array}$ & \multicolumn{2}{|c|}{ Current location } & \multicolumn{2}{c}{$\begin{array}{c}\text { Highest level of } \\
\text { education }\end{array}$} \\
\hline & Somalia & Dadaab & Dadaab & Nairobi & Canada & $\begin{array}{c}\text { Secondary } \\
\text { school }\end{array}$ & $\begin{array}{c}\text { Some } \\
\text { higher } \\
\text { education }\end{array}$ \\
Male & 14 & 14 & 8 & 3 & 3 & 8 & 6 \\
Female & 7 & 7 & 4 & 0 & 3 & 4 & 3 \\
\hline
\end{tabular}


Table 3. Basic characteristics of survey respondents $(n=248)$

\begin{tabular}{|c|c|c|c|c|c|c|c|}
\hline \multicolumn{2}{|c|}{ Country of Birth } & \multicolumn{2}{|c|}{ Country of residence } & \multicolumn{2}{|c|}{$\begin{array}{l}\text { Highest Level of Education } \\
\text { Completed }\end{array}$} & \multicolumn{2}{|c|}{ Age (years) } \\
\hline Somalia & $79 \%$ & Somalia & $9 \%$ & Secondary school & $12 \%$ & $18-19$ & $3 \%$ \\
\hline USA & $3 \%$ & USA & $35 \%$ & Some post-secondary & $12 \%$ & $20-30$ & $61 \%$ \\
\hline UK & $0.4 \%$ & UK & $7 \%$ & Diploma/certificate & $13 \%$ & $31-40$ & $21 \%$ \\
\hline Canada & $1 \%$ & Canada & $17 \%$ & Bachelor's degree & $38 \%$ & $41-50$ & $10 \%$ \\
\hline Kenya & $7 \%$ & Kenya & $14 \%$ & Master's degree + & $18 \%$ & +50 & $5 \%$ \\
\hline Other & $11 \%$ & Other & $18 \%$ & Other & $7 \%$ & & \\
\hline
\end{tabular}

\begin{tabular}{|c|c|c|c|c|c|}
\hline \multicolumn{2}{|c|}{ Lived in a refugee camp } & \multicolumn{2}{|c|}{$\begin{array}{l}\text { Length of residence in } \\
\text { camp }\end{array}$} & \multicolumn{2}{|c|}{ Distribution among camps } \\
\hline Yes & $51 \%$ & $1-5$ years & $31 \%$ & Dadaab (Kenya) & $70 \%$ \\
\hline \multirow[t]{5}{*}{ No } & $49 \%$ & $6-10$ years & $14 \%$ & Kakuma (Kenya) & $7 \%$ \\
\hline & & $11-15$ years & $11 \%$ & Utanga (Kenya) & $4 \%$ \\
\hline & & $16-20$ years & $21 \%$ & Liboi (Kenya) & $2 \%$ \\
\hline & & $21+$ years & $23 \%$ & Jijiga (Ethiopia) & $2 \%$ \\
\hline & & & & Other & $15 \%$ \\
\hline
\end{tabular}


Table 4. Sources of Virtual Support

\begin{tabular}{|c|c|c|c|c|c|c|c|c|c|c|c|c|c|c|c|c|}
\hline & \multicolumn{4}{|c|}{ Academic Support $(n=87)$} & \multicolumn{4}{|c|}{ Career Guidance $(n=53)$} & \multicolumn{4}{|c|}{ Social Support $(n=39)$} & \multicolumn{4}{|c|}{ Emotional Support $(n=33)$} \\
\hline & \multicolumn{2}{|c|}{ Full sample } & \multicolumn{2}{|c|}{ Camp } & \multicolumn{2}{|c|}{ Full sample } & \multicolumn{2}{|c|}{ Camp } & \multicolumn{2}{|c|}{ Full sample } & \multicolumn{2}{|c|}{ Camp } & \multicolumn{2}{|c|}{ Full sample } & \multicolumn{2}{|c|}{ Camp } \\
\hline & M & $\mathrm{F}$ & M & $\mathrm{F}$ & M & $\mathrm{F}$ & M & $\mathrm{F}$ & M & $\mathrm{F}$ & M & $\mathrm{F}$ & M & $\mathrm{F}$ & M & $\mathrm{F}$ \\
\hline Teachers & $59 \%$ & $43 \%$ & $56 \%$ & $44 \%$ & $53 \%$ & $46 \%$ & $52 \%$ & $50 \%$ & $46 \%$ & $27 \%$ & $44 \%$ & $33 \%$ & $56 \%$ & $13 \%$ & $64 \%$ & $25 \%$ \\
\hline Family & $24 \%$ & $20 \%$ & $25 \%$ & $13 \%$ & $29 \%$ & $31 \%$ & $19 \%$ & $33 \%$ & $67 \%$ & $67 \%$ & $56 \%$ & $33 \%$ & $56 \%$ & $69 \%$ & $55 \%$ & $75 \%$ \\
\hline Friends & $44 \%$ & $47 \%$ & $36 \%$ & $50 \%$ & $58 \%$ & $46 \%$ & $57 \%$ & $67 \%$ & $83 \%$ & $87 \%$ & $75 \%$ & $33 \%$ & $75 \%$ & $75 \%$ & $73 \%$ & $100 \%$ \\
\hline Student peers & $41 \%$ & $60 \%$ & $42 \%$ & $69 \%$ & $39 \%$ & $31 \%$ & $29 \%$ & $50 \%$ & $46 \%$ & $40 \%$ & $44 \%$ & $67 \%$ & $50 \%$ & $19 \%$ & $55 \%$ & $25 \%$ \\
\hline
\end{tabular}


Table 5. Mechanisms of Virtual Support

\begin{tabular}{|c|c|c|c|c|c|c|c|c|c|c|c|c|}
\hline & \multicolumn{4}{|c|}{ Academic Support $(n=87)$} & \multicolumn{4}{|c|}{ Career Guidance $(n=53)$} & \multicolumn{4}{|c|}{ Social Support $(n=39)$} \\
\hline & \multicolumn{2}{|c|}{ Full sample } & \multicolumn{2}{|c|}{ Camp } & \multicolumn{2}{|c|}{ Full sample } & \multicolumn{2}{|c|}{ Camp } & \multicolumn{2}{|c|}{ Full sample } & \multicolumn{2}{|c|}{ Camp } \\
\hline & M & $\mathrm{F}$ & M & $\mathrm{F}$ & M & $\mathrm{F}$ & M & $\mathrm{F}$ & M & $\mathrm{F}$ & M & $\mathrm{F}$ \\
\hline Email & $67 \%$ & $67 \%$ & $61 \%$ & $56 \%$ & $68 \%$ & $38 \%$ & $67 \%$ & $33 \%$ & $63 \%$ & $40 \%$ & $56 \%$ & $100 \%$ \\
\hline Phone & $56 \%$ & $67 \%$ & $56 \%$ & $75 \%$ & $42 \%$ & $31 \%$ & $33 \%$ & $50 \%$ & $92 \%$ & $93 \%$ & $94 \%$ & $100 \%$ \\
\hline Text messaging & $33 \%$ & $30 \%$ & $36 \%$ & $19 \%$ & $21 \%$ & $23 \%$ & $14 \%$ & $33 \%$ & $50 \%$ & $80 \%$ & $56 \%$ & $100 \%$ \\
\hline Facebook & $30 \%$ & $20 \%$ & $25 \%$ & $6 \%$ & $37 \%$ & $31 \%$ & $33 \%$ & $33 \%$ & $63 \%$ & $60 \%$ & $63 \%$ & $33 \%$ \\
\hline $\begin{array}{l}\text { Discussion } \\
\text { boards }\end{array}$ & $19 \%$ & $27 \%$ & $22 \%$ & $31 \%$ & $13 \%$ & $15 \%$ & $14 \%$ & $17 \%$ & $8 \%$ & $13 \%$ & $13 \%$ & $0 \%$ \\
\hline
\end{tabular}


Table 6. Prioritizing Non-Academic Types of Support $(n=178)$

Full sample Camp

\begin{tabular}{lcccc} 
& $\mathrm{M}$ & $\mathrm{F}$ & $\mathrm{M}$ & $\mathrm{F}$ \\
\hline Career Guidance & $35 \%$ & $20 \%$ & $31 \%$ & $29 \%$ \\
Social Support & $22 \%$ & $24 \%$ & $24 \%$ & $14 \%$ \\
Emotional Support & $15 \%$ & $25 \%$ & $16 \%$ & $19 \%$ \\
\hline
\end{tabular}

